\title{
E-commerce and M-commerce as Global Trends of International Trade Caused by the Covid-19 Pandemic
}

\author{
ILONA DUMANSKA ${ }^{1}$, LESYA HRYTSYNA ${ }^{2}$, OLENA KHARUN ${ }^{3}$, OLHA MATVIIETS ${ }^{4}$ \\ 1, 2, 3, ${ }^{4}$ Department of International Economic Relations, Khmelnytskyi National University, Ukraine
}

Abstract: - The article examines the impact of the COVID-19 pandemic on international trade and identifies e-commerce and m-commerce as its global trends. A scientific and methodological approach to the study of the vector and specifics of the development of e-commerce and m-commerce is formed given the lack of necessary statistical information to assess the state of e-commerce in a country and linguistic features of definitions. The influence of e-commerce and $\mathrm{m}$-commerce on the online shopping and sales industry has been established. The global distribution of Internet sources used by consumers, global sales in m-commerce as a percentage of e-commerce and the impact of the coronavirus pandemic on online traffic and changes in transactions by industry are analyzed. The transition of e-commerce to m-commerce was revealed as a result of the increase in the share of mobile transactions in view of the development of markets in countries focused primarily on mobile devices and their active use. As a result of the post-pandemic forecast in the trends of international trade and e-business priorities, a promising increase in world sales in e-commerce has been established. The main trends of further development of e-commerce and $\mathrm{m}$-commerce in the field of international trade are identified, such as: big data, personalization, e-mail marketing, transition of e- commerce to e-commerce, ordering services online and transition of retail to online, electronic public procurement, omnichannel and multichannel, socially oriented commerce, improved work with the community and the need for efficient logistics.

Key-Words: - e-commerce, m-commerce, international trade, e-business, online shopping, online sales, transactions, goods, Internet, pandemic COVID-19.

Received: January 2, 2021. Revised: April 12, 2021. Accepted: April 19, 2021. Published: April 23, 2021.

\section{Introduction}

No one doubts that life after the pandemic will no longer be the same as before, because the whole world is living by the new rules for the second year in a row. During the COVID-19 pandemic, almost all business processes in the field of international trade were affected, in particular in the commercial real estate markets around the world. Restrictions imposed by governments on the operation of shopping malls, service outlets, catering, entertainment and leisure have led to changes in consumer behavior and, as a consequence, to dynamic sales growth in e-commerce and $\mathrm{m}$ commerce.

According to a study by EVO [1], the amount of online purchases during 2020 increased by $41 \%$. In turn, the attendance of shopping centers decreased by $20-45 \%$ (depending on the country), if we compare the data for the six months of 2020 with the same period in 2019. There is a sharp increase in consumer activity in e-commerce and m-commerce, which has fundamentally influenced the transformation of international trade, associated with the development of technology, the blurring of borders in the sale of goods, changing consumer habits. Thus, the world of e-commerce for the last six months of 2020 has reached a five-year work plan.

In the context of global transformations involved in pandemics, the world economy is changing cash flows in the field of e-business, which indicates the growing influence of the Internet on global economic processes. Forced to stay at home due to global lockdown, society is discovering the latest technologies. The modern consumer in real time can view the range of products sold, quickly find the right product, find out its characteristics, read the reviews of other consumers, choose a convenient method and time of delivery, make online payments not through a desktop computer, and via mobile phone.

The COVID-19 pandemic also contributed to the emergence of new trends in international trade based on e-commerce and mobile commerce. Given this fact, the need to develop scientific and methodological approaches to the study of the 
trajectory and features of e-commerce and $\mathrm{m}$ commerce, analysis of their impact on the online shopping and sales industry, post-pandemic forecast in international trade trends and e-business priorities.

\section{Literature Review}

Research of theoretical and applied scientific aspects of e-business form the e-commerce and $\mathrm{m}$ commerce in the scale of international electronic commerce engaged in such foreign scholars as $\mathrm{V}$. Zwass V., A. Sammer, Gr. Duncan, D. Koze, W. Triez and L. Stewart.

In his works, the American researcher V. Zwass [2] studied in detail the conceptual and categorical apparatus of e-business, identified areas of ecommerce and m-commerce, gave them such different characteristics from other business processes in international trade as business information exchange, debugging business relations, business transactions through telecommunications networks (including mobile communications), as well as trade relations. We state that the scientist focuses on the business side of these concepts.

A. Sammer and Gr. Duncan [3] share the views of V. Zwass and define e-commerce as any form of business process in which interaction between entities takes place electronically.

D. Koze [4] in his fundamental works emphasizes the concept of $\mathrm{m}$-commerce to ecommerce, defining the latter in a broader sense, in particular, notes the following: networks, but today this concept has expanded significantly and includes trade in fundamentally new types of goods, such as information in electronic form. Obviously, this view is based only on the study of e-commerce, which is carried out using computer networks, while mobile communications and the acceleration of purchases through its use remains unnoticed.

An intermediate point of view on the business and trade side of e-commerce and m-commerce is described by W. Triez and L. Stewart [5], arguing that they include the use of technology in the financial business, electronic ticket reservations, deliveries, orders, and the use of the Internet to buy and sell goods and services, including after-sales services and support.

Recent research in the field of e-commerce and $\mathrm{m}$-commerce has divided researchers into two groups.

The first group thoroughly approaches the analysis of e-commerce, without highlighting the segment of m-commerce. Thus, R. AbuRaya [6] conducted a broad-based analysis of the prospects of e-commerce policy and business intelligence statistics in terms of promoting ethical values in preventing illegal and unauthorized e-commerce practices. Continuing her work is the research of Nnamdi J. Ogbuke, Yahaya Y. Yusuf, Kovvuri Dharma \& Burcu A. Mercangoz [7], who conceptually explored the ethical, confidential and security issues of e-commerce from the standpoint of Big Data. Ye Shi, Ting Wang, Layth C. Alwan [8] emphasize the role of cross-border parameters of e-commerce in terms of risk management. The works of these scientists indicate the existence of demand in the field of e-commerce research, however, they do not pay attention to the impact of the coronavirus pandemic on e-commerce, which forms new trends in international e-commerce and catalyzes its diffusion in all industries.

Another group of scientists analyzes mcommerce separately from e-commerce, but only from the standpoint of international system calculations and e-wallets. Among them are studies such as A. Acker and D. Murthy [9] on methods of mobile payments and evaluation of mobile operating systems for financial transactions, J. Clement [10] in terms of mobile applications for online shopping and mobile wallets, H Qasim and E. Abu-Shanab [11] on the ability to perform transactions without location or time restrictions. In [12-13] proposed scientific and methodological approach for estimating emergent properties, where the information base became the dynamic changes in the functioning of mechanical engineering enterprises. These studies address a valuable aspect of the intensification of international e-commerce through mobile communications as a method and method of fast payment, but do not describe the trend of shifting e-commerce to m-commerce, taking into account a number of other important factors, including the COVID pandemic.

\section{Problem Formulation}

Given the significant contribution of the authors to the formation of theoretical and practical aspects of e-commerce and m-commerce, dynamic and rapid changes in the segment of international ecommerce there is a need for detailed research, generalization, study of mechanisms and features of various factors on e-commerce trends and $\mathrm{m}$ commerce in modern conditions of the covid pandemic, because this aspect in their works is unexplored due to the dynamics of environmental change. 
The publication presents e-commerce and $\mathrm{m}$ commerce as global trends in international ecommerce caused by the pandemic, which actualizes their justification as important tools and solutions for consumers, defining their role in supporting business and increasing the competitiveness of the economy both domestically and internally. and in the international trade segment. It is worth noting that social distancing, the development of mobile technologies and significant limitations have highlighted the importance of digital technologies in e-business and are shifting the focus of e-commerce to the $\mathrm{m}$ commerce segment.

Given this, there is a need for research in the publication of such issues as: defining the essence of e-commerce and m-commerce in the segment of international e-commerce, the formation of scientific and methodological approaches to vector research and specifics of e-commerce and $\mathrm{m}$ commerce; determining the impact of the COVID19 pandemic on the main trends in e-commerce and m-commerce; separation of the dominant development of m-commerce over e-commerce on the basis of modern trends in improving the sales system on the Internet; analysis of the latest trends in e-commerce and m-commerce in terms of pandemic challenges and its forecasts for the postpandemic period.

\section{The Research Methods}

The following methods were used in this publication: analysis, synthesis, scientific abstraction, historical method - to determine the essence of the categories of e-commerce and mcommerce in the segment of international Internet trade; causal method and comparison - to determine the impact of the COVID-19 pandemic on the main trends in e-commerce and m-commerce; graphic method, grouping and generalization - to form a scientific and methodological approach to the study of the vector and specifics of e-commerce and mcommerce, given the lack of necessary statistical information to assess the state of e-commerce in a particular country; statistical comparisons and comparative analysis - to study the impact of ecommerce and $\mathrm{m}$-commerce on the online buying and selling industry, analysis of global sales in $\mathrm{m}$ commerce as a percentage of e-commerce, the impact of the coronavirus pandemic on online traffic, changes in transactions by industry and forecasting its impact; abstract-logical and theoretical generalization - in the field of research of the transition of e-commerce in m-commerce and establishing their main trends of further development in the field of international trade and ebusiness.

\section{Problem Solution}

Analysis of the development of e-commerce at the international level is associated with certain difficulties, the main of which are linguistic features. E-commerce, as well as e-commerce and ebusiness were formed in the United States, which led to the use in international acts and agreements, such as, for example, «UNCITRAL Model Law on Electronic Commerce», the English term «ecommerce». In this case, the term «e-commerce» means «any trade agreements for the supply of goods or services or exchange of goods or services; distribution agreements; commercial representation and agency relations; factoring; leasing; construction of industrial facilities; provision of consulting services; engineering; purchase / sale of licenses; investment; financing; banking services; insurance; operating agreements or concessions; joint ventures and other forms of industrial or business cooperation; transportation of goods and passengers by air, sea, by rail or road «" [14]. Thus, at the international level there is no definition of ecommerce as an independent form of doing business, and hence its analysis is carried out in fragments within the framework of establishing the peculiarities of e-commerce.

E-commerce is part of the e-commerce sector such as Business-to-Consumer (B2C), which is evaluated annually by UNCTAD. The UNCTAD B2C E-commerce Index includes an assessment of indicators such as the proportion of the population using home delivery services; share of the population using credit cards (15+); the share of Internet users and the number of secure servers for sowing Luxembourg, which is characterized by the highest security performance of the global network.

Norway, Finland, Canada, Germany, the Republic of Korea and Israel are also in the top ten countries in terms of B2C E-commerce. The United States ranks 15th in the ranking, Russia - 50, Ukraine - 58, China - 65 [15]. However, it should be noted that this index covers mostly the infrastructural aspect of the development of electronic international trade and does not allow to identify further trends in its development as an economic phenomenon.

Today, it is difficult to assess the state of development of e-commerce in a particular country due to the lack of necessary statistical information. 
In addition, the available statistical information is insufficiently complete due to the fact that national and international statistical services in the survey do not cover the entire list of enterprises, and some enterprises hide real data on their activities [16]. Mcommerce and e-commerce statistics can be displayed on the seller's website, in the buyer's mobile gadgets, but this is fragmented information that requires comprehensive analysis, not selective. Under such conditions, it is advisable to introduce a scientific and methodological approach to the study of the vector and specifics of the development of ecommerce and m-commerce, which is presented in Figure 1 as a sequence of actions in eight stages.

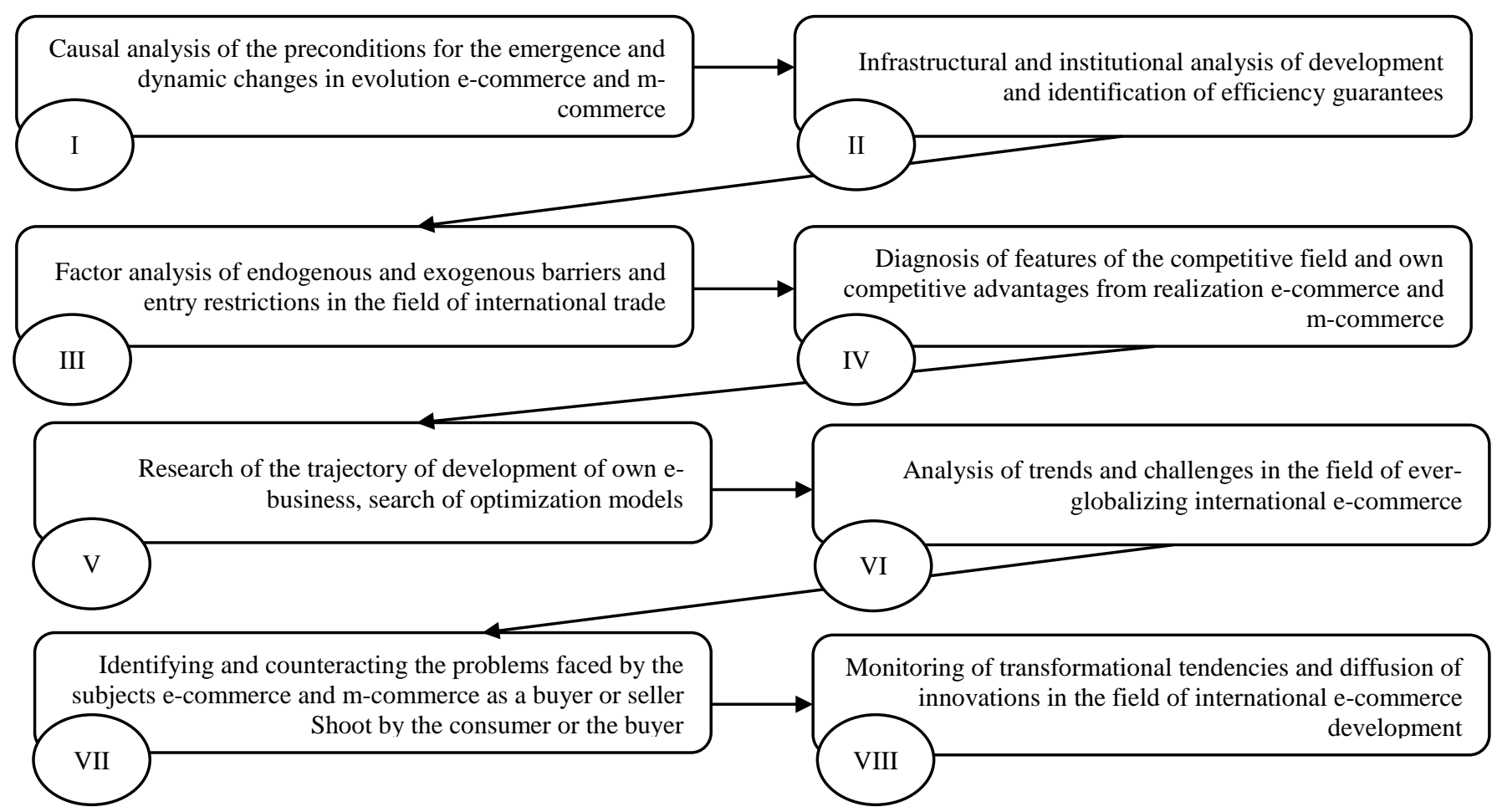

Figure 1: Scientific and methodological approach to the study of the vector and specifics of development ecommerce and m-commerce *

Source: authors' development *

Within the framework of the proposed scientific and methodological approach, given the lack of official statistics in the field of e-commerce and $\mathrm{m}$ commerce, there is a possibility of conducting a comprehensive analysis of their development at each stage of implementation. In particular, it is possible to study the preconditions for changes in the segment of e-commerce and m-commerce on the basis of assessing the evolution of their systems and changes (Phase I) and explore their infrastructure by identifying the effectiveness of implementation for a business entity (Phase II). Based on the results of such preliminary assessments, which determine the development of e-commerce, further analyze the factors that constitute restrictions in international trade, which include restrictions on intergovernmental organizations to import and export quotas under international agreements (Phase III).

After establishing the absence of barriers at the previous stage, diagnose the competitive field and assess the prospects for additional opportunities from the implementation of e-commerce, including on the basis of formation of competitive advantages (Phase IV). Based on the results of stages I-IV, research on the trajectory of development of own ebusiness is carried out and its optimization models are searched in various forms of online trade from online trading platforms to individual e-shops (Phase V). After determining the initial prerequisites and organizational principles, a trend analysis of ecommerce and m-commerce models for compliance with the requirements of the modern business environment, which is influenced by globalization trends (Phase VI).

One of the important stages is to identify and counteract the problems faced by e-commerce and m-commerce entities as buyers or sellers (Phase VII). It is at this stage that possible abuses by participants in international e-commerce, which are mostly related to the information sphere, are identified. Thus, one of the biggest dangers is cyber 
attacks on critical information infrastructure and personal data of participants in e-commerce relations, which have been constantly carried out by various cyber groups for the last 5 years. Some of them have caused significant material damage, including the infamous Petya Ransomware virus, which has affected more than 60 countries and caused $\$ 8$ billion in damage [17]. Equally important is the issue of fraudulent schemes in ecommerce. For example, the actions of unscrupulous sellers who demand advance payment for the goods and do not deliver it are typical; unscrupulous buyers who lure valuable goods under postpay schemes, malicious software, Internet begging, fake raffles under the guise of winning a valuable prize, etc.

Accordingly, monitoring of transformation trends and diffusion of innovations in the field of international e-commerce (Phase VIII) is extremely important, as the use of innovations in not only Internet marketing but also cybersecurity will create favourable conditions for business development that can be cross-border through Internet opportunities.

Thus, the implementation of the presented scientific and methodological approach to the study of the vector and specifics of e-commerce and $\mathrm{m}$ commerce, in contrast to existing approaches to the implementation of e-commerce and m-commerce on the basis of physical, online and ethical standards, is based on a sequence of actions and a comprehensive approach to research that will provide reliable information on the state of international trade, taking into account the evolution of online sales, identify competence constraints on the development of e-business opportunities and online shopping, identify competition in these business processes and identify a number problems that accompany ecommerce and mobile commerce, including cybercrime and various forms of fraud.

\subsection{E-commerce and the world's leading online stores}

E-commerce is the electronic purchase or sale of goods through online services or the Internet. Over the past few years, e-commerce has become an integral part of the global retail system. Retailers meet demand determined by the supply chain. The term «retailer» is commonly used when a service provider fulfills small orders from many end users, rather than large orders from a small number of wholesale, corporate, or government customers. As in many other industries, retail has undergone significant changes not only since the advent of the Internet, but also during anti-pandemic measures, and thanks to the ongoing digitalization of modern life, consumers from almost all countries have now benefited from online transactions. As access to and distribution of the Internet grows rapidly around the world, the number of digital buyers worldwide continues to grow every year. In 2019, about 1.92 billion people bought goods or services online. In the same year, e-commerce sales worldwide exceeded $\$ 3.5$ trillion, and according to the latest estimates, e-commerce growth will accelerate even more in the future [18].

Internet users can choose from a variety of online platforms to view, compare and purchase the goods or services they need. Although some websites specifically target B2B (business-to-business) customers, individual consumers are also provided with a huge number of digital opportunities. As of 2020, online trading sites account for the largest share of online shopping worldwide. Amazon leads in the global ranking of online retail stores in terms of traffic. The e-commerce giant from Seattle, which offers e-retail, computer services, consumer electronics and digital content, registered more than 5.2 billion unique visitors in June 2020. However, in terms of gross value of goods (GMV), Amazon ranks third after China, competitors Taobao and Tmall. Both platforms are operated by Alibaba Group, Asia's leading online retailer. For example, Figure 2 shows that 63 percent of online shoppers switch to Amazon to start searching for products. 


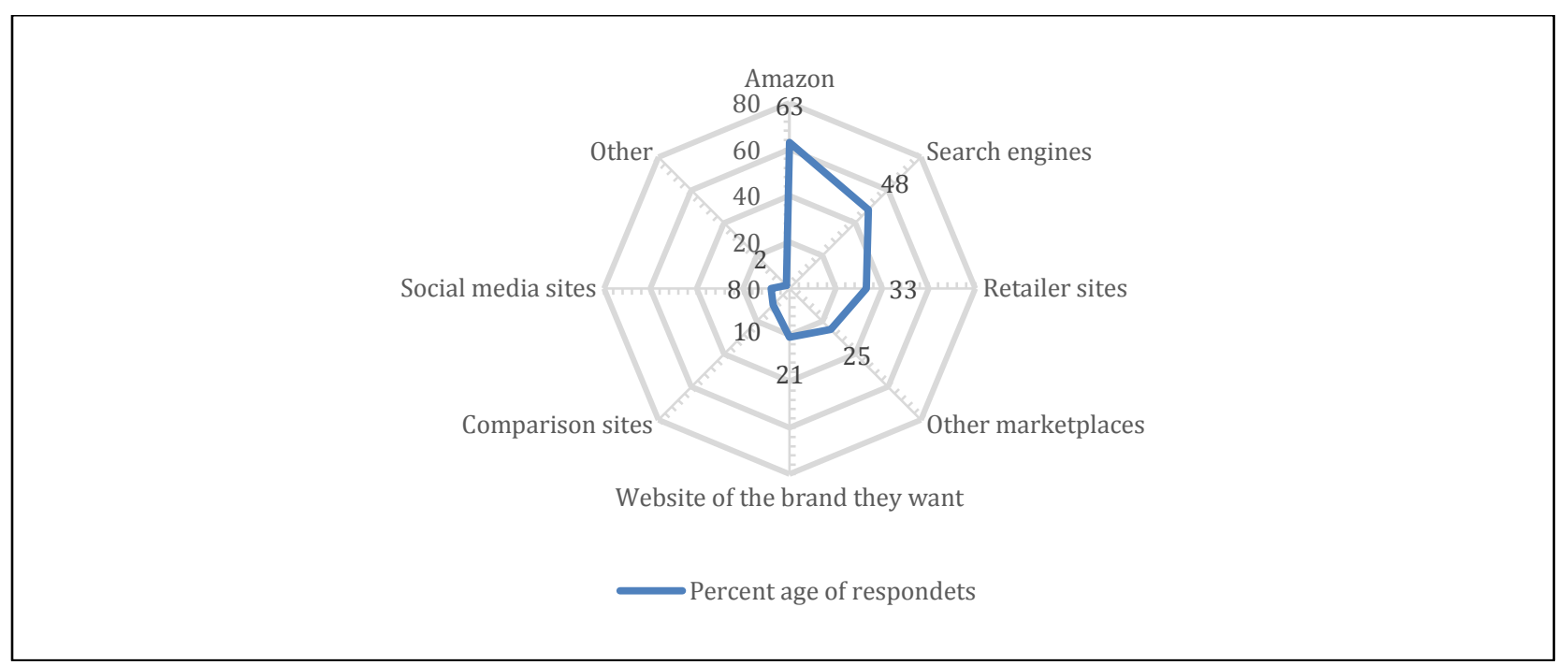

Figure 2: Distribution of Internet sources used by consumers worldwide under the option «Product Search» for $2020, \%[19]$

\subsection{M-commerce - mobile communication increases global e-commerce traffic}

One of the most noticeable trends in the world of e-commerce is the unprecedented use of mobile devices. The term «m-commerce», which means mobile commerce, also means - viewing, buying and selling products or services through mobile devices. In other words, it is a full-fledged online purchase, which is most convenient to make from a mobile phone (tablet), which acts as the main user interface for a number of services. In 2019, smartphones accounted for more than 67 percent of all retail website visits worldwide. As the deployment of mobile devices is rapid, especially in regions where there is no other digital infrastructure, mobile integration will continue to determine the shopping experience in the future. m-commerce is especially popular in Asian countries: where up to 65 percent of total online transactions are generated through mobile traffic [20]. Mobile retail sales as a percentage of e-commerce retail worldwide from 2016 to 2021 are presented in Figure 3.

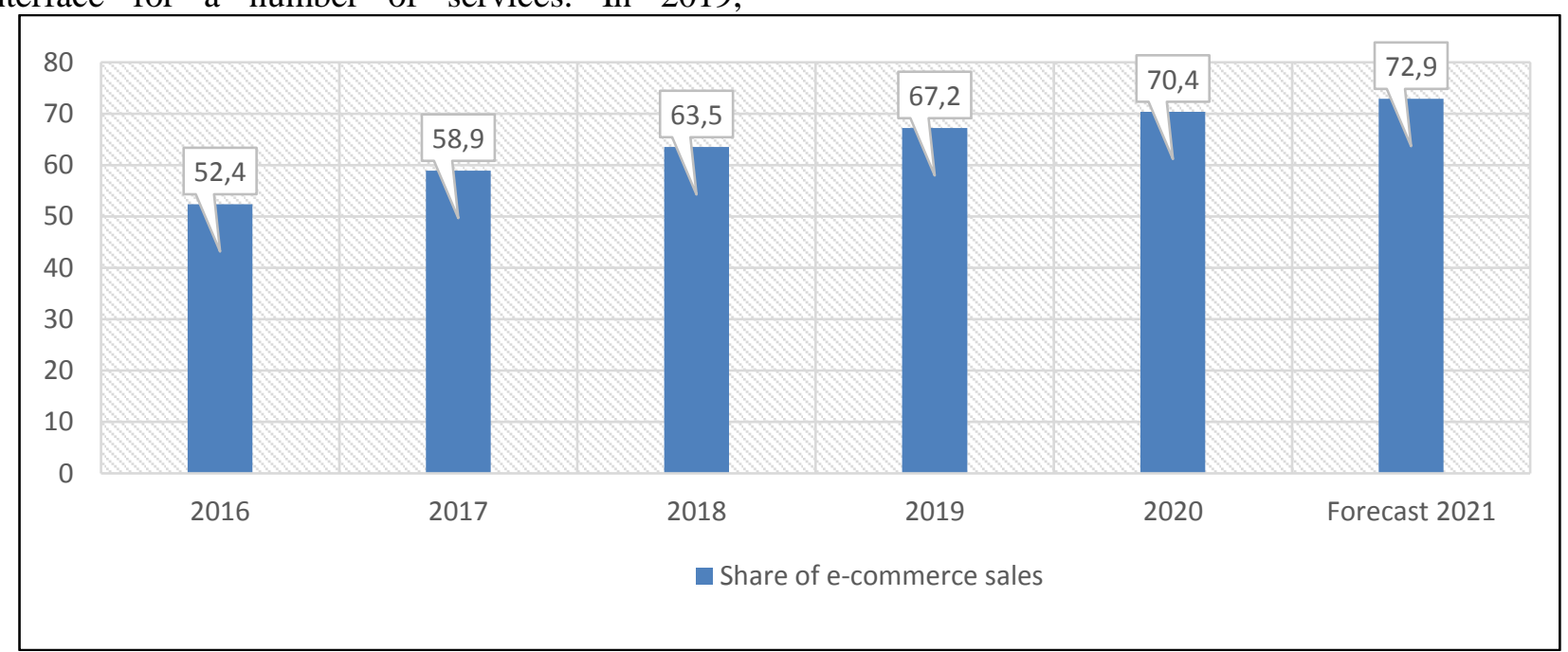

Figure 3: Sales in m-commerce as a percentage of e-commerce worldwide, 2016-2021,\% [20]

These statistics provide information on the share of mobile retail sales as a percentage of total retail e-commerce sales worldwide from 2016 to 2021. It is expected that in 2021, 72.9 percent of all e- commerce retail will be generated through mobile commerce, compared to 58.9 percent in 2017 [18]. E-commerce markets, which are developing in countries focused primarily on mobile devices, are 
an important driver of this trend.

\subsection{Impact of e-commerce and m-commerce under COVID-19 on the online shopping industry}

The coronavirus pandemic (COVID-19) continues to have a significant impact on ecommerce and online consumer behavior around the world. Since millions of people stayed home in early 2020 to curb the spread of the virus, digital channels have become the most popular alternative to crowded shops and personal shopping. In June 2020, global e-commerce retail traffic reached a record 22 billion visits per month, with extremely high demand for everyday goods such as food, clothing, and retail technical goods. How the use of the Internet, shopping habits and the common future of the e-commerce market will look like in 2021 and beyond will largely depend on the spread of COVID-19 [19]. As more and more cities and regions around the world take isolation measures, consumer models are changing, reflecting new needs and ways to adapt to new realities. Figure 4 shows the impact of the coronavirus pandemic on online traffic by industry, and Figure 5 shows changes in transactions by industry.

Given the restrictions on the introduction of coronavirus pandemic in tourism and entertainment (traffic decline is $-57 \%$ ) it is obvious ranking the needs of the population in terms of priority provision of physiological food needs and daily life (increase $+161 \%$ ) and information needs as recommendations for action (media growth $+80 \%$ and telecom $+32 \%$ ) in the field of online traffic, reflecting the statistics in Figure 4.

Trends in transactions by industry show the leading positions of marketplace / tech retail growth $(+48 \%)$, and the banking / insurance industry (+ $40 \%$ ) is not far behind due to the active development of Internet banking, while similarly in the tourism segment $(-81 \%)$ and entertainment ($45 \%$ ) decline.

Also, the transaction trends in Figure 5 duplicate the indicators of online traffic in Figure 4 in the context of the decline in the luxury, fashion and jewelry segments due to the uncertainty of the timing of the introduced lockdown and the declining purchasing power of the population.

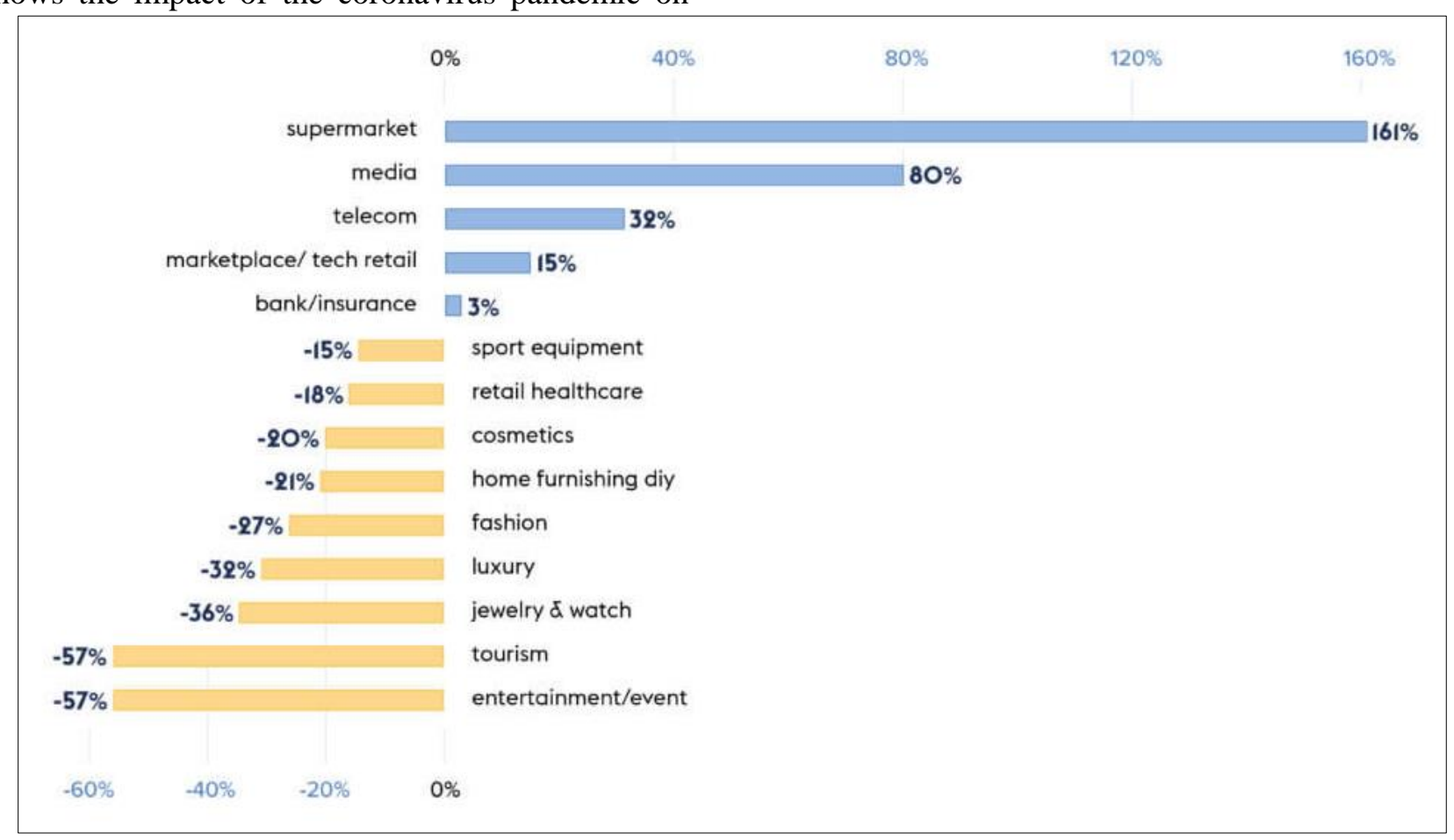

Figure 4: Impact of coronavirus pandemic on online traffic in \% by industry [21] 


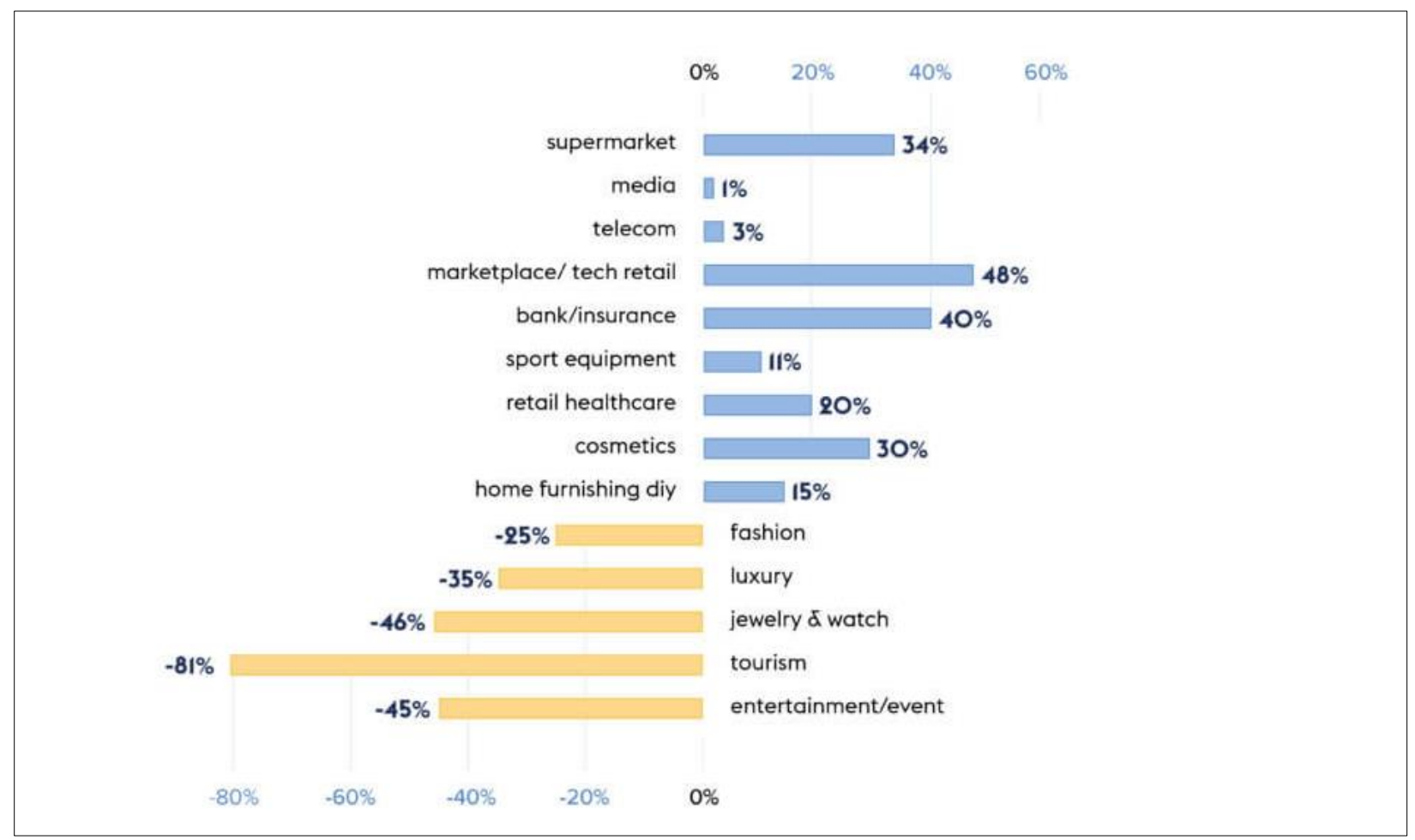

Figure 5: Impact of coronavirus pandemic on transaction changes in $\%$ by industry [21]

\subsection{Forecast of e-commerce and m-commerce in the post-pandemic period}

According to the WHO [22], as of July 2, 2020 , there were $10,458,422$ confirmed cases of the disease in the world, 511,082 patients died. In contrast to China and other countries in the East Pacific, where the spread was clustered, in European countries, the disease has spread throughout the community, complicating measures to combat the pandemic.

According to IMF estimates [22], the decline in world GDP in 2020 is expected at $3 \%$, primarily due to a decline in developed countries - by $6.1 \%$, in the European Union - by 7.1\%. In general, in developing countries (with an emerging market), the decline is projected to be much smaller - by $1.0 \%$, and in China and India, a slight increase of +1.0 and $+1.2 \%$, respectively. In a much larger part of the world (up to $90 \%$ of all countries) compared to 2009 (about 60\%) there will be a drop in GDP per capita (Figure 6). The gradual recovery of the world economy will reach $5.8 \%$ in 2021.

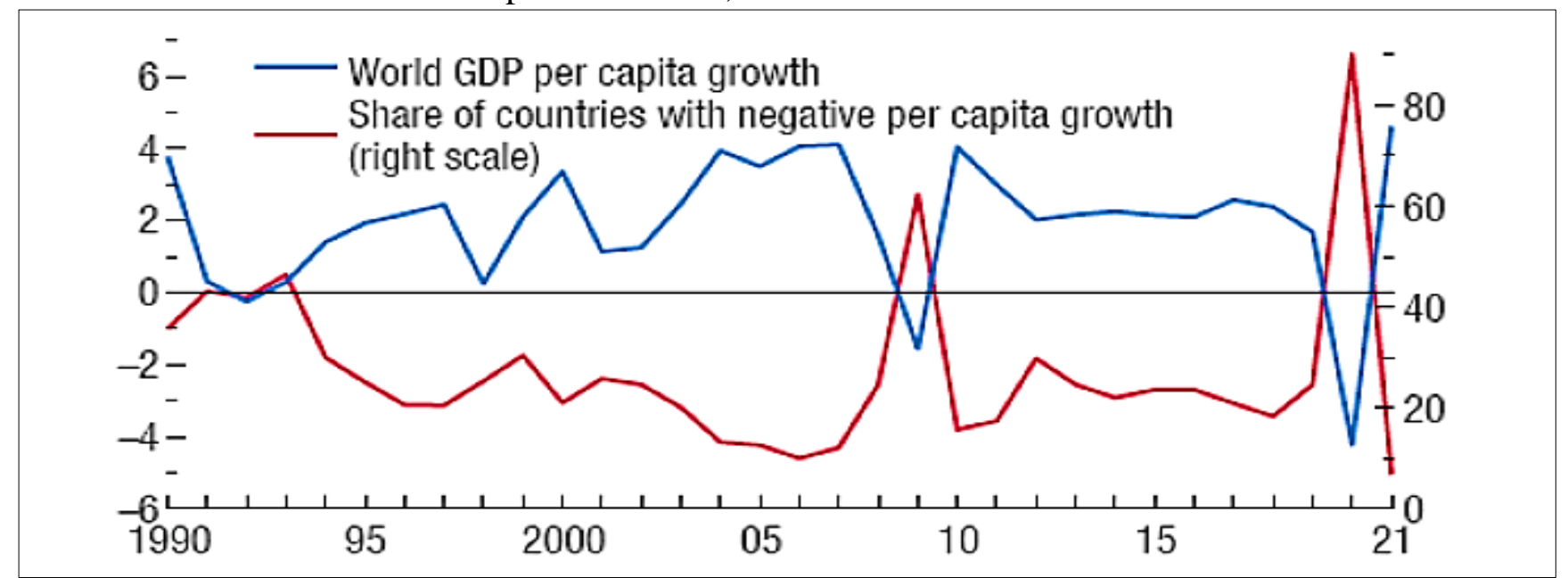

Figure 6: IMF forecast for the dynamics of world GDP per capita for 2020-2021 [23] 
The main basic assumptions of the IMF regarding the impact of the pandemic on the world economy and the economies of individual countries include:

- the pandemic will end in the second half of 2021, which will gradually remove the restrictions;

- the main shocks for the economies of almost all countries will occur in the second quarter of 2021. Except for China, where the decline occurred in the first quarter. The speed of recovery depends on the time required to start production after suspension. The loss of working time in general will be about $5 \%$;

- the state of financial markets will improve in the second half of 2021

The basic assumption of the IMF is also the growth of world trade by $15.4 \%$ in 2021 [23], despite the global economic crisis due to the reset of economic strategies and the maximum simplification of complex logistics chains for the supply of resources and sales of goods through IT. Such assumptions further actualize the development of e-commerce and the peculiarities of its development in the postpandemic period from the standpoint of the consumer group.

Thus, according to the Global Consumer Survey Report for 2019, it is established that investing in the quality of customer service should be a priority for business. In addition to measuring ROI (return on investment), companies must also begin to measure ROX (return on experience) and determine how increasing customer satisfaction scales their business, including in the post pandemic period. The most dynamic e-commerce market in the world is China. By 2021, m-commerce will occupy $72.9 \%$ of the e-commerce market. Most online customers prefer to pay by credit card. About $51 \%$ of online shoppers shop via smartphones. There are more than 2 billion digital buyers in the world. There are 12 to 24 million e-commerce sites in the world. Global e-commerce B2C sales are expected to reach \$ 4.5 trillion by 2021 . The fastest growth in ecommerce in the period from 2018 to 2022 is expected in India and Indonesia. E-commerce retail sales accounted for $14.1 \%$ of global retail sales in 2019 [24]. Figure 7 presents the global sales of e-commerce as a confirmation of the stated forecasts.

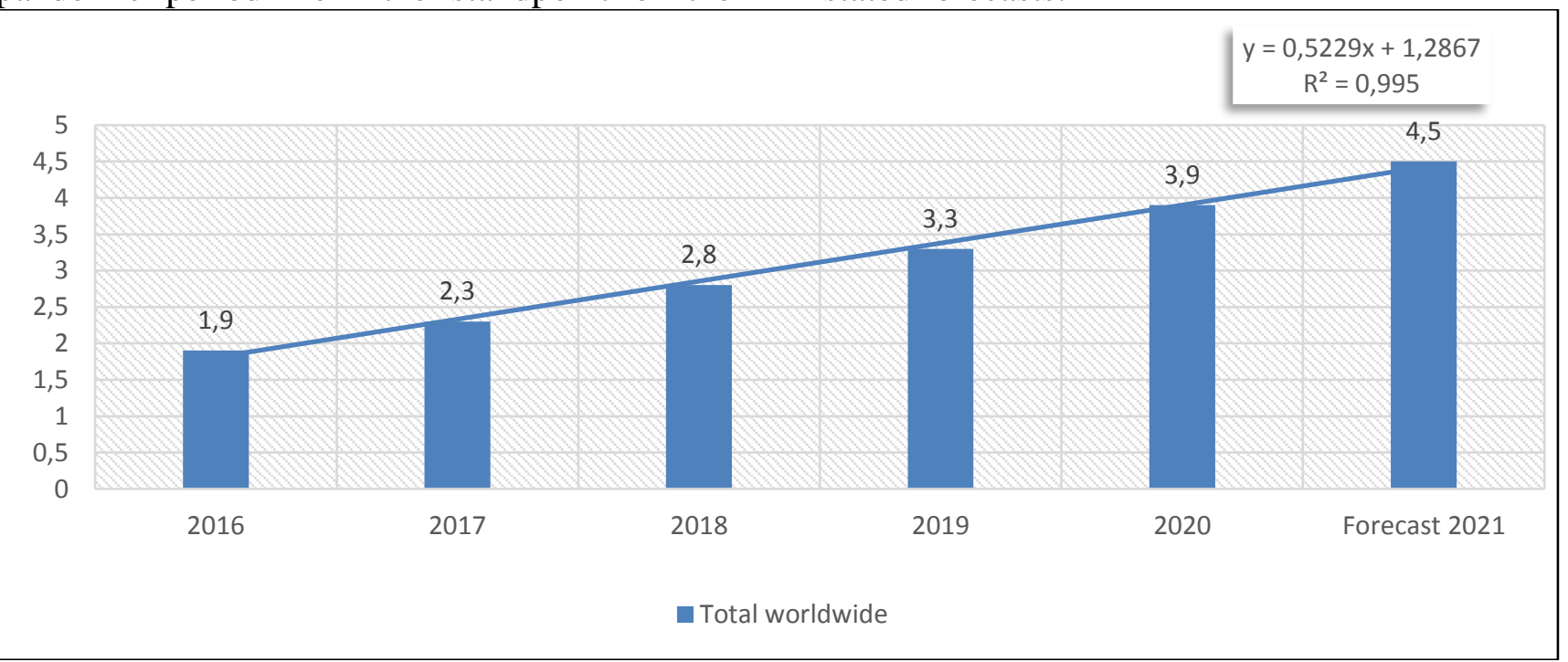

Figure 7: World sales of e-commerce, trillion US dollars [18]

The analysis of world sales in e-commerce presented in Figure 7 and their forecast for 2021 were analyzed on the basis of a linear approximation [23]. The smoothing used in this case is described by the following formula:

$$
y=a x+b
$$

following form:

$$
y=-0.1156 x+72.255
$$

The value of the reliability of the approximation in our country is equal to $\mathrm{R} 2=0.9418$, which is a fairly acceptable result, which characterizes the smoothing as reliable for the forecast for 2021. 


\subsection{E-commerce and m-commerce trends and challenges of international trade}

To the main trends of e-commerce and mcommerce in the field of international trade it is expedient to include:

1. Big data. In e-business, it is used to analyze user data of an online resource, improve customer service, optimize search, targeted advertising, user segmentation, determine the customer life cycle and develop marketing programs.

2. Personalization is the adaptation of an online store, product offers, prices and other content for a specific user who has currently entered the electronic resource.

3. E-mail marketing as an effective tool to increase online store sales.

4. The transition from e-commerce to mcommerce is an increase in the share of mobile transactions. Since the beginning of 2016, the number of purchases from mobile devices has doubled compared to the same period last year. Today, one in five online shoppers uses a mobile device to select and order goods, and in 2 years, one in two will make purchases from a mobile.

5. Ordering services online and the transition of retail to online - this trend is actively responding to the largest retail networks, which are developing their sites, building a new communication with customers online.

6. E-procurement is a new market for eservices for government agencies that minimizes bureaucratic procedures and corrupt practices at the level of government officials.

7. Omnichannel and multichannel providing the company with a single price, reliable and up-to-date information about its products in all sales channels, the ability for the buyer to choose the most convenient way of communication and provide the ability to complete the transaction regardless of communication [24].

8. Socially oriented commerce. In recent years, the number of transactions that have taken place on social networks is growing. But these are very ambiguous options for development, because it is difficult to understand how effectively all this is converted into sales.

9. Improving community work. Most shoppers study other people's reviews before ordering goods online. Buyers do this not only on the seller's website, but also on other resources to get the most complete information about the product. The most popular is usergenerated content - reviews, comments, reviews, questions / answers.

10. Effective logistics. The real problem of the Ukrainian e-commerce market is the high cost of delivery. Sometimes this becomes an obstacle to buying cheap goods online due to the high cost of delivery.

\section{Conclusion}

The COVID-19 crisis has accelerated the spread of e-commerce and m-commerce through new firms, customers and product types through changes in demand from conventional business processes in international trade to ecommerce. This gave customers free access to a wide variety of goods without leaving home, and allowed companies to continue to operate despite quarantine restrictions and lockdowns.

E-commerce and m-commerce transactions in many countries have partially shifted from luxury goods and services to everyday necessities that are relevant to a large number of people. Some of these changes are in the context of international e-commerce are likely to be long-term in light of the new waves of the pandemic, the convenience of new shopping habits, training costs and incentives for companies to benefit from investing in new sales channels. A new direction of international e-commerce is gaining popularity -mcommerce, given the universality of mobile gadgets and improving the quality and accessibility of mobile communications.

It is difficult to assess the state of development of e-commerce in Ukraine due to the lack of necessary statistical information. To address this shortcoming, we have proposed a scientific and methodological approach to the study of the trajectory and features of ecommerce and m-commerce, which will provide reliable information on the state of international trade, including online sales, 
identify competencies to develop e-business opportunities. and online shopping, identify the specifics of competition in these business processes and identify a number of problems that accompany e-commerce and mobile commerce, including cybercrime and various forms of fraud.

To the main trends of e-commerce and $\mathrm{m}$ commerce in the field of international trade it is expedient to carry: big data, personalization, email marketing, transition e-commerce in $\mathrm{m}$ commerce, with reservation of services on the Internet and the transition of retail to online, eprocurement, omnichannel and multichannel, with socially oriented commerce, improved work with the community and the need for efficient logistics.

In our next works, we will explore ways to address the identified challenges in the development of e-commerce and m-commerce against the background of international ecommerce by protecting vulnerable consumers from unfair business practices and dangerous goods, and will seek reserves to create innovative business e-commerce models with guaranteed flexibility of the regulatory framework for combining online and offline business functions.

\section{References:}

[1] Yarovaya M. The results of the e-commerce market according to EVO: 107 billion UAH for online purchases. Retrieved from https://ain.ua/2020/12/25/pidsumky-2020-evo/

[2] Zwass V. Electronic Commerce: Structures and Issues. International Journal of Electronic Commerce, 1, 1996, pp. 3-23

[3] Sammer A., Dunkan Gr.? Marketing. The fifth wave. Moscow : E-commerce. 1999

[4] Koze D., E-commerce. Russkaya redaktsiya, Moscow. 1999

[5] Treese C. Winfield, Stewart Lawrence C., Designing Systems for Internet Commerce. AddisonWesley. 1998

[6] AbuRaya R. Business Analytics of ECommerce Policy and Practice: An Ethical Perspective. International Conference on Decision Aid Sciences and Application (DASA), 2020, pp. 761-767.

[7] Nnamdi Johnson Ogbuke, Yahaya Y. Yusuf, Kovvuri Dharma \& Burcu A.
Mercangoz. Big data supply chain analytics: ethical, privacy and security challenges posed to business, industries and society, Production Planning \& Control (special issue), 2020. doi.org:10.1080/09537287.2020.1810764

[8] Ye Shi , Ting Wang, Layth C. Alwan Analytics for Cross- Border E- Commerce: Inventory Risk Management of an Online Fashion Retailer. Decision Sciences, 51 (6), 2020, pp. 13471376 doi.org:10.1111/deci.12429

[9] Acker A., Murthy D., 2018. Venmo: understanding mobile payments as social media. SMSociety '18: Proceedings of the 9th International Conference on Social Media and Society. July 2018, pp. 5-12. doi.org: 10.1145/3217804.3217892

[10] Clement J. Mobile payments worldwide - statistics \& facts. March 2021. Statista.com Retrieved from https://www.statista.com/topics/779/mobile-internet/

[11] Qasim, H., Abu-Shanab, E. Drivers of mobile payment acceptance: The impact of network externalities. Inf Syst Front 18, 2016, pp. 10211034. doi.org: 10.1007/s10796-015-9598-6

[12] Voynarenko M., Hurochkina V., Sushkova O., Yepifanova I. (2021). Beneficial ownership chain and its evaluation arrangement. Studies of Applied Economics, 38, (4). doi: http://dx.doi.org/10.25115/eea.v38i4.3991

[12] Voynarenko M, Dzhedzhula V., Hurochkina V., Yepifanova I., Menchynska, O. (2021). Applying Fuzzy Logic to Modeling Economic Emergence WSEAS Transactions on Business and Economics, 18, 424-433. DOI: 10.37394/23207.2021.18.43

https://www.wseas.org/multimedia/journals/eco nomics/2021/a865107-012(2021).pdf

[14] UNCITRAL, (1996). Model Law on ECommerce. Retrieved from http:// www.uncitral.org/uncitral/ru/uncitral_texts/electroni c_commerce.html (in Russ.)

[13] UNCTAD, (2015). Information economy report. Report of United Nations Conference on Trade and Development. Retrieved from http://unctad.org/en/ pages/PublicationWebflyer.aspx?publicationid=114 6

[14] Malovychko S. Analysis of the state and features of the development of international ecommerce. Economic Annals-XXI, 7-8(1), 2015, pp. 17-19.

[15] The damage from the attack of the Petya.A virus in the world reaches 8 billion dollars - expert Unian.

Retrieved from 
https://www.unian.ua/science/2003241-zbitki-vidataki-virusu-petyaa-syagayut-8-milyardiv-dolarivekspert.html

[16] Yudin A. World E-commerce and Mcommerce - statistics and facts of e-commerce 2020. Marketer.ua. Retrieved from https://marketer.ua/ua/e-commerce-worldwidestatistics-facts/

[17] Distribution of Internet sources used by consumers around the world under the «Product Search» option. Retrieved from https://www.statista.com/statistics/1034209/globalproduct-search-online-sources/

[18] Sales in m-commerce as a percentage of ecommerce worldwide, 2016-2021. Retrieved from https://www.statista.com/statistics/806336/mobileretail-commerce-share-worldwide/

[19] The impact of the coronavirus pandemic on online traffic in $\%$ by industry. The impact of the coronavirus pandemic on changes in transactions in $\%$ by industry. Retrieved from https://contentsquare.com/blog/impact-ofcoronavirus-on-ecommerce-consumers-settle-intoquarantine/

[20] Coronavirus disease 2019 (COVID19). 18.04.2020. Situation Report - 89. World Health Organization. Retrieved from https://www.who.int/docs/defaultsource/coronaviruse/situation-reports/20200418sitrep-89-covid-19.pdf

[21] World economic outlook. The great lockdown. April 2020. Chapter 1. International monetary fond. Retrieved from. https://www.imf.org/en/Publications/WEO/Issues/2 020/04/14/weo-april-2020

[22] Pobochenko L., Sabatin O. Development of Internet trade in Ukraine under the influence of world trends. World economy and international economic relations, 6 (11), 2017, pp. 9-14.

[23] Everitt B., Horthorn T. A handbook of statistical analyses using R. Chapman and HALL/CRC. 2009, 376 p.

\section{Contribution of individual authors to the creation of a scientific article (ghostwriting policy)}

Ilona Dumanska was formed of research ideas, made general guidance.

Lesya Hrytsyna was responsible for the Statistics.

Olena Kharun has implemented data analysis and implementation of modeling in figures.
Olha Matviiets was responsible for Literature review, organized description of results and translation.

\section{Sources of funding for research presented in a scientific article or scientific article itself}

Personal funds of the authors

\section{Creative Commons Attribution \\ License 4.0 (Attribution 4.0 \\ International , CC BY 4.0)}

This article is published under the terms of the Creative Commons Attribution License 4.0

https://creativecommons.org/licenses/by/4.0/deed .en_US 